\title{
A educação e a arte nos entrelugares da rua
}

Marina Moreto ${ }^{1}$

\begin{abstract}
RESUMO
Como se dá a educação na rua? Qual encontro é necessário? Qual encontro é permitido? Há educação na rua? Há meninos e há educadores nas ruas, uma relação acontece. Um entrelugar efêmero brota. Para regar o broto: arte. Canetinhas, papéis, pipas, varetas, tintas, olhos, corpos, trabalho, suor. Este texto apresenta uma pequena amostra de dados coletados para pesquisa de mestrado apresentada à Faculdade de Educação da Unicamp, caracterizando-se por um trabalho etnográfico sobre o fazer de educadores sociais e meninos de rua, em Campinas/SP. Observa-se a relação estabelecida entre esses pares, esses corpos educadores entre si. O encontro suficientemente bom de educadores e meninos os leva a construir saberes e metodologias que fazem surgir as possibilidades além rua, da droga, da contenção. A relação entre educadores e meninos confirma que uma grande aliada para a solidificação do vínculo e construção do processo educativo é a criatividade e o fazer das mãos.
\end{abstract}

\section{PALAVRAS-CHAVE}

Educação; Arte; Situação de rua

\section{Education and art: the space between in the street}

\begin{abstract}
How is education in the street? What kind of meeting is necessary? What meeting is allowed? Is there is education on the street? There are boys and educators in the streets, a relationship happens. An ephemeral 'between-space' flows. To water the bud: art. Pens, papers, pipes, rods, paints, eyes, bodies, work, sweat. This paper presents a small sample of data collected for a research in master's degree presented to the College of Education at Unicamp, an ethnographic work on making educators and street children in Campinas (Brazil). I watched the relationship between these peers, these 'educators-bodies' themselves. A good meeting among educators and boys permits them to build knowledge and methods that reveal the possibilities beyond the street, the drug, restraint. The relationship among them confirms that a great ally for the build up of educational processes is creativity and the use of hands.
\end{abstract}

\section{KEYWORDS}

Education; Art; Homeless

\footnotetext{
${ }^{1}$ Mestre em Educação pelo Laborarte - Laboratório de Estudos sobre Arte, Corpo e Educação, da Faculdade de Educação UNICAMP e Geógrafa. Atualmente atua como Coordenadora Pedagógica do Protagonismo Juvenil da ONG (Organização Não-Gevernamental) CPTI - Centro Promocional Tia Ileide, em Campinas/SP, e também como professora de Geografia para ensino médio. E-mail: ma.biju@gmail.com - Campinas, SP, Brasil.
} 


\section{PRÓLOGO}

Este texto mostra um recorte da pesquisa de mestrado realizada entre os anos de 2008 - 2010 na Casa Guadalupana, trazendo análises, imagens, documentos desse processo. A Casa Guadalupana era um serviço integrante da Instituição Padre Haroldo - Campinas / SP - que desenvolvia arte-educação nas ruas com meninos e meninas em situação de rua. Neste tipo de atividade uma dupla de educadores levavam às ruas uma caixa com materiais artísticos e lúdicos e uma colcha, que eram dispostos nas ruas onde estavam os meninos. Esse espaço criado esteticamente na rua servia para educadores e meninos fazerem arte, brincarem, vincularem-se. Havia também oficinas de arte-educação matinais, em espaço fechado, além de atendimentos psicológicos e atendimentos com assistentes sociais. Esta Casa encerrou suas atividades em meados de 2010 .

Fui arte-educadora da Casa Guadalupana de 2006 a 2007, quando então passei a coordená-la. Iniciei esta pesquisa em 2008, enquanto exercia a função de coordenadora. Em agosto de 2009 passei a fazer parte da coordenação de quatro serviços que atendiam situação de rua na Instituição Padre Haroldo: a Casa Guadalupana, dois abrigos e um pernoite. Em julho de 2010 desliguei-me da instituição, dando continuidade à pesquisa.

Desta forma, durante dois anos e meio (dos três anos) da pesquisa de mestrado, estive ligada diretamente ao trabalho cotidiano da Casa Guadalupana. Era afetada como pesquisadora pelas tarefas cabíveis à coordenadora, tinha assuntos a resolver, muitos problemas diários, alegrias, angústias, dores, e, sobretudo (que é o que me impulsionou nesta pesquisa), uma paixão pelo trabalho desenvolvido pelos educadores com os meninos e meninas de rua.

Fui uma observadora participante imbricada dos pés à cabeça com o trabalho dos educadores, assim como com o trabalho da minha pesquisa. Eu vivi, vi, senti, ri, chorei, tive medo e muita coragem em toda a trajetória como educadora, coordenadora e pesquisadora. Esta pesquisa também é a história de um pedacinho da minha vida. Foi na Casa Guadalupana que descobri a educação social com arte e os meninos de rua, e devido a esse apaixonante trabalho me aproximei da psicanálise winnicottiana ${ }^{2}$ e do Laborarte ${ }^{3}$.

\footnotetext{
${ }^{2}$ A psicanálise winnicotiana baseia-se no autor Donald W. Winnicott.

${ }^{3}$ Laborarte - Laboratório de Estudos sobre Arte, Corpo e Educação, da Faculdade de Educação, Universidade Estadual de Campinas - UNICAMP. "O Laborarte desenvolve estudos sobre arte, corpo e educação, em suas diferentes linguagens, tempos e espaços, tratando de temas que abrangem educação estética, educação física e políticas culturais" (Trecho retirado do site oficial do Laborarte: http://www.fe.unicamp.br/laborarte.).
} 
A pesquisa qualitativa realizada possuiu um caráter longitudinal (BAUER; GASKELL, 2007), isto é, toquei vários pontos no tempo e concentrei minha análise em experiências e ações coletivas. Apliquei nove entrevistas individuais com educadores sociais de rua (que desenvolviam atividades em espaços abertos) e três com arte-educadores (que desenvolviam atividades em espaços fechados). Utilizei técnicas de entrevistas semiestruturadas, a fim de ouvir a voz dos educadores sobre qual era o seu fazer pedagógico com os meninos e meninas. As entrevistas contaram com a construção de um tópico-guia (BAUER; GASKELL, 2007) como norte da conversa.

Além das entrevistas analisei documentos da Casa Guadalupana, como relatórios e planos de trabalho. Utilizei os materiais produzidos pelos meninos e educadores - poesias, desenhos, cartas, fotos e vídeos - para tentar captar o que acontecia entre os educadores e meninos, qual era o entrelugar ${ }^{4}$ que aparecia.

Durante a pesquisa produzi fotos de atividades entre os meninos e educadores, saí para atividades de rua com os educadores, filmei alguns momentos, fotografei o ambiente da Casa Guadalupana e pedi a alguns educadores relatos, poesias, crônicas que expressassem suas vivências com os meninos.

Busquei atender a duas premissas de "boas práticas" (BAUER; GASKELL, 2007, p. 474) no processo de investigação: formulação de proposições e prestação de contas pública. Conforme apontam os autores:

As proposições baseadas na pesquisa empírica de qualquer tipo devem ir além da mera conjetura ou intuição. É necessária uma evidência que dê garantia às proposições que são feitas em uma arena pública em nome da ciência social /.../. A prestação de contas pública /.../ é a idéia de que a ciência opera em um espaço público. Não é um empreendimento privado. Suas proposições e garantias, a fim de se qualificarem como conhecimento público, são "objetificadas" e tornadas públicas, e por isso estão abertos ao escrutínio público. (BAUER; GASKELL, 2007, p. 481).

\footnotetext{
${ }^{4}$ Empresto o termo "entrelugar" das minhas vivências no Laborarte, em que buscamos desfrutar dos entrelugares do corpo e da arte com o pensamento, as palavras, os olhares, a dança, o papel e os vídeos. Em agosto de 2010 aconteceu o $2^{\mathbf{0}}$ Seminário Internacional de Educação Estética - Entrelugares do Corpo e da Arte, organizado pelo Laborarte, onde também foi lançado o Dossiê Entrelugares do Corpo e da Arte (PROPOSIÇÕES, v. 21, n.2 (62), maio / ago. 2010. São Paulo: UNICAMP, Faculdade de Educação, 1990-. Quadrimestral. ISSN 0103-7307). Na apresentação deste Dossiê, as autoras nos conduzem a compreender o que significa entrelugar: "Pensar nos lugares do corpo e da arte na vida humana leva-nos, inescapavelmente, aos entrelugares, aos desvãos, aos esconderijos onde o inexplicável, poeticamente, também se faz presente... Colocanos numa posição onde não estamos nem lá nem cá, desafiando nosso desejo de encontrar um refúgio seguro. As relações entre corpo e arte são sempre e simultaneamente zonas de aproximação e distanciamento, de claridade e escuridão, de transparência e opacidade, porque entremeadas pelas múltiplas histórias do mundo que as vão entrelaçando, urdindo, enredando, como a cerzideira que vai tramando os fios e magicamente faz desaparecer as costuras que constituem o tecido" (STRAZZACAPPA; ALBANO; AYOB, 2010, p. 15). Este também é o sentido de entrelugar que utilizo neste trabalho.
} 


\section{COMO ERA A CASA}

Dentro de um conjunto articulado de serviços e programas sociais de Campinas, a Casa Guadalupana atendia especificamente crianças e adolescentes que faziam das ruas seu espaço de sociabilidade e moradia e que poderiam estar em intenso uso de substâncias psicoativas.

Observei que a Casa Guadalupana era um espaço para os meninos e meninas em situação de rua brincarem. O espaço físico da Casa Guadalupana era um espaço de brincadeira, esteticamente cuidado, decorado pela relação educador-menino, os desenhos e poesias estava estampados nas paredes. Era o fazer dessa união que aparecia como entrelugar.

Já o espaço da Casa Guadalupana na rua, também era um espaço de brincadeira, visto que a colcha, os educadores e a caixa lúdica construíam uma espécie de instalação artística em plena calçada, instalação essa que tinha o intuito do fazer, portando do brincar. Esse espaço também era esteticamente modelado. A Casa Guadalupana em espaço aberto, ao mesmo tempo em que se descolava da realidade cotidiana da rua, criando um universo particular, se misturava a ela, fazendo parte e causando interferência na vida de quem por ali passava no momento da brincadeira.

Sendo também a rua um espaço culturalmente construído para brincadeiras de crianças, que hoje se retrai nos grandes centros urbanos, será que o fazer dos educadores não provocava recordações, lembranças, memórias e fantasias nos transeuntes?

Um pequeno trecho de entrevista com um dos educadores alimenta uma resposta para esta questão. No decorrer da entrevista pedi ao educador que me descrevesse quais eram as atividades que ele desenvolvia na rua, e ele me respondeu:

Eu gosto muito de trabalhar com tinta, gosto muito de pintar o chão, de pintar a praça, estender um papel Kraft grande, assim, prender com durex nas árvores $e$ pintar livre, gosto muito de giz, de chão, ultimamente a gente joga muita bola, de arte mesmo a gente faz desenhos, em grande escala, porque eu gosto de coisas que chamam a atenção. (Entrevista com o educador Índigo, 09/09/2009) ${ }^{5}$

Depois pergunto se os meninos interagiam com a atividade:

Alguns sim, outros a gente sente que sentavam, desenhavam... foi, foi... desenhou qualquer coisa, levantou e foi embora, não que esse desenho não signifique nada, mas sei lá, eu gosto muito que eles interajam com a gente e interajam com as pessoas que estão passando, por isso que eu gosto de coisas grandes assim, pra dar visibilidade. (Entrevista com o educador Índigo, 09/09/2009)

\footnotetext{
${ }^{5}$ Todas as transcrições de entrevistas estão destacadas por uma moldura, para diferenciá-las das citações bibliográficas.
} 
Sigo perguntando como as pessoas que estavam passando perto da atividade observavam aquela cena, e ele me diz:

É uma loucura assim, tem um ambiente que é o Extra ${ }^{6}$, é um ambiente que a gente fica bem do lado de onde passam os carros, as pessoas olham, as pessoas xingam, as pessoas acham que a gente é maluco, as pessoas mexem com a gente demais, $e$ olham, olham sempre. (Entrevista com o educador Índigo, 09/09/2009)

É interessante notar que o educador deseja realizar atividades que deem visibilidade à cena que está acontecendo no local, ele gosta de trabalhar com coisas que chamem a atenção e conclui dizendo que as pessoas olham e olham sempre. Essa é a relação que esse educador espera que aconteça com o ambiente circundante.

Ele também espera que os meninos - o foco principal de seu serviço - interajam com sua proposta pedagógica / artística, e ainda mais, que interajam com as pessoas que passam na rua. A imagem que faço dessa cena é de uma intervenção artística urbana.

Com os elementos que observei no campo de pesquisa e que coletei nas entrevistas, imagino essa cena da seguinte forma:

Uma esquina de um semáforo movimentado de Campinas, no cruzamento entre um hipermercado, uma universidade e bairros populosos; educadores com uma colcha estendida na calçada; papéis Kraft pregados nas árvores com durex; pincéis pelo chão; guache no painel; giz desenhando o chão; carros passando, carros passando; ônibus buzinando; xingos; assovios; meninos no rodinho; meninos vindos do uso de crack; meninos pintando o painel; educadores pintando o painel; educador e menino chutando uma pequena bola...

Essa cena é incomum nas esquinas da cidade. Essa cena interagia com as pessoas na rua, indubitavelmente. Essa cena é um lugar entre dois mundos. É um entrelugar.

\section{COMO ERA O PLANO DE TRABALHO}

Apresento a Justificativa do trabalho desenvolvido pelos educadores no Plano de Trabalho $2010^{7}$ apresentado pela Instituição Padre Haroldo à SMCAIS ${ }^{8}$. O conteúdo é retirado na íntegra do referido Plano 9 :

\footnotetext{
${ }^{6}$ O Extra refere-se a uma região próxima ao Supermercado Extra Abolição, onde aconteciam atividades periódicas da Casa Guadalupana.

${ }^{7}$ O Plano de Trabalho é o documento que norteia as metas, os objetivos, a metodologia de trabalho e os resultados esperados, que é enviado anualmente pelas Instituições à SMCAIS para que seja analisado, avaliado e a partir dele possa se firmar o contrato de co-financiamento. Este processo prevê três etapas: $1^{\circ}$ confecção do plano de trabalho do serviço; $2^{\mathbf{0}}$ Aprovação do plano pela Diretoria da Instituição; $3^{\circ}$ Aprovação do plano pela SMCAIS; $4^{\circ}$ Encaminhamento ao CMAS (Conselho Municipal de Assistência Social), pela SMCAIS, das
} 
A Casa Guadalupana enfrenta a Situação de Rua de crianças e adolescentes analisando a conjuntura sócio-espacial do Município. Para tanto corroboramos aspectos culturais, econômicos, sociais, jurídicos, temporais, psicológicos e espaciais a fim de desenvolvermos criticamente a educação social de rua, a arteeducação e o atendimento psicossocial. Assim, entendemos que a continuidade de nosso trabalho contribui para a transformação de indivíduos fragilizados sócioespacialmente a colocarem-se de maneira cidadã e autônoma. Pelos processos desenvolvidos multidisciplinarmente construímos situações educativas e terapêuticas que ofereçam sustentação para que os(as) meninos(as) e seus familiares se coloquem de maneira ativa em suas vidas. Contamos com a Rede e com os poderes público e privado para parcerias nesta transformação da realidade sócio-espacial.

Acessamos mensalmente por volta de 65 meninos(as) e 30 jovens. Com cerca de $80 \%$ desenvolvemos educação social de rua. As Oficinas aproximam os meninos da Casa, aumentando o vínculo destes(as) com o equipamento, e gerando outras demandas, como atendimentos, acompanhamentos, referenciamentos e encaminhamentos. Destes $80 \%$, cerca de $60 \%$ são atendidos constantemente pelas duas duplas psicossociais, o restante estas duplas têm contatos breves e discussão dos casos com os educadores e a Rede. A contratação de mais DUAS duplas psicossociais é fundamental para maior abrangência do trabalho.

Consideramos que o trabalho se dá em três vertentes: educação social de rua, arteeducação nas oficinas e atendimento psicossocial. (PLANO DE TRABALHO, 2010).

A justificativa para o trabalho abordava desde aspectos mais gerais sobre o município de Campinas até a análise de um aspecto micro, o fazer cotidiano do serviço. Isso é interessante, pois denotava uma preocupação em compreender a situação de rua em sua totalidade, considerando suas causas e possibilidades dentro do contexto no qual se insere a sociedade. Assim, o foco da questão da situação de rua não recaía apenas sobre o indivíduo, mas partir para a análise da conjuntura social e política.

No momento seguinte o Plano de Trabalho defendia a continuidade do serviço, para que o trabalho de transformação do indivíduo fragilizado não sofresse quebras e possibilitasse que ele se colocasse de maneira cidadã no mundo.

Uma vez que as palavras podem ser interpretadas de muitas maneiras, ressalto uma fragilidade do texto do Plano de Trabalho: a frase "transformação de indivíduos fragilizados sócio-espacialmente a colocarem-se de maneira cidadã e autônoma" poderia significar adequá-los à sociedade, adaptá-los, fazê-los caber, reintroduzi-los socialmente, caso olhássemos de modo assistencialista ou com uma visão marginalizadora da situação de rua. Por isso é importante analisar os documentos paralelamente às entrevistas e imagens.

propostas de serviços a serem co-financiadas; $5^{\circ}$ Aprovação dos planos pelo CMAS; $6^{\circ}$ Assinatura do Termo de Ajuste de co-financiamento entre SMCAIS e Instituição.

${ }^{8}$ SMCAIS - Secretaria Municipal de Cidadania, Assistência e Inclusão Social da Prefeitura Municipal de Campinas / SP.

${ }^{9}$ Todos os grifos estão no original. 
Como diz Freire (1978), “o que pretendem os opressores é transformar a mentalidade dos oprimidos e não a situação que os oprime” (FREIRE, 1978, p. 69).

Por outro lado, este mesmo parágrafo da justificativa remete aos elementos freireanos da construção pedagógica, onde a postura crítica e a análise da realidade vivida fazem com que a tomada de consciência seja um aspecto fundamental para a educação libertadora. Freire $(1978 ; 1996 ; 2007)$ reforça inúmeras vezes a importância da desalienação dos educadores e dos educandos, isto é, que haja uma comunicação entre eles capaz de superar as contradições que os unem. Então, vejo que quando no Plano de Trabalho era dito que a Casa Guadalupana tinha a intenção de criar situações multidisciplinares que promovessem os meninos e seus familiares para se colocarem de maneira ativa e cidadã, o serviço considerava-os sujeitos do processo, não vazios à espera de conteúdo, mas com conteúdos potenciais, capazes de estabelecer diálogos entre si e com o mundo.

Pelo aspecto retórico, da intenção, uma concepção libertadora de educação fica clara. No entanto, fica a pergunta: como realizavam essa prática? Essa é uma pergunta complexa, e seguramente existem abordagens distintas para tentar cercá-la. Então, sem o intuito de respondê-la, vou analisá-la:

Começo descrevendo os desafios enfrentados à realização dessa prática:

Um dos desafios enfrentados para a prática da educação libertadora se dava nos debates com a rede de serviços e com o poder público. No Plano de Trabalho é mencionada a intenção da transformação social conjunta com estas instâncias, e vejo que havia certa provocação nesta convocação, pois ao fazer a transformação conjunta, certamente as contradições apareceriam, e seria justamente esse o momento em que algumas mudanças poderiam ocorrer.

Além deste desafio, havia também desafios práticos, que ilustro num trecho de entrevista com o educador Grená quando perguntei como é feito o trabalho de educação na rua:

Depende dos meninos, da idade, dos lugares. Mas é mais efêmero é mais difícil porque os meninos que vêm na Guadalupana já tem um contato com uma rede onde eles estão mais ou menos no cotidiano do atendimento que os da rua não estão, necessariamente, ou ainda não se vincularam aos serviços ou não tão no momento ligados à ele, e precisa de diferentes motivações pra se ficar na rua, mas eu acho que o que dificulta bastante a comunicação é o uso do crack que, enfim, que faz com que a pessoa fique numa correria ali que não é essa de sentar e conversar. Mas outros não, outros são mais tranquilos e dá pra conversar, mas aí é bem efêmero mesmo, /.../ costuma ser muito amistoso chegar e estender a colcha e o material de atividades e criar um espaço diferente. (Entrevista com o educador Grená, 30/10/2009) 
Observo que é delicado o chegar na rua, que apesar de amistoso, havia diferentes momentos de meninos e meninas, alguns já mais "acostumados" com a presença dos educadores, outros menos. Havia também a presença do crack, que dificultava sentar junto e comunicar-se. Perguntei em seguida como era esse estender a colcha:

É estender uma colcha literalmente como um cobertor ou alguma coisa assim e é uma criação de um espaço lúdico, é uma coisa parecida com o lar também, é um convite. Na verdade aí fica uma coisa muito interessante porque a gente convida no sentido de que a gente tá mostrando que a gente tá desarmado, né, que a gente tá disposto, a gente quer conversar, trocar idéia sem julgamento, sem preconceito, isso é legal, mas também a gente tá no espaço deles, e eles também convidam a gente a tá no espaço. Então quando funciona, funciona muito bem. (Entrevista com o educador Grená, 30/10/2009)

Analiso que essa passagem demonstra possivelmente uma prática de educação não bancária, visto o modo como Grená descreveu como eles chegavam à rua. O educador afirmou que eles chegavam em um lugar que não é o deles, eles chegavam no lugar dos meninos e relatou que havia um ritual de observações e cuidados com o ambiente. Os educadores estendiam uma colcha "como um lar" e convidavam os meninos a sentarem-se ali com eles.

Desse modo, conforme disse Grená, eles mostravam que estavam ali numa postura pacífica, com o intuito de conversarem sem julgamento e preconceito. Vejo que essa era uma premissa fundamental da educação que praticavam: que é o respeito ao outro. $\mathrm{O}$ educador concluiu dizendo que os meninos também convidavam os educadores a estarem ali, no lugar deles. Analiso que acontecia uma troca.

Em seguida perguntei a Grená se acontecia alguma comunicação no estender da colcha, e ele me diz:

Eles chegam, alguns chegam, eles saem, uma boa parte deles senta e conta a história dele, sua história de vida ou conta coisas do dia-a-dia de agressão policial, dependendo do lugar quase todo dia, e tratam a gente como amigo mesmo. (Entrevista com o educador Grená, 30/10/2009)

Os meninos confiavam aos educadores contar-lhes suas vidas, as agressões, como um amigo. Embora o termo amigo não seja usado para a relação educador-educando, faço a leitura do "amigo", nesse caso, como alguém que se tem um vínculo e se pode confiar. E vejo nessa relação de amizade uma comunicação horizontal e generosa.

Sigo a entrevista perguntando qual tipo de material eles levavam para a colcha, para promover essa comunicação: 
Tinta, papel, jogos, instrumentos musicais, algum livrinho ou também o estatuto, o ECA o Estatuto da Criança e do Adolescente, um rádio são coisas assim que dê pra desenvolver com eles. (Entrevista com o educador Grená, 30/10/2009)

Pela resposta de Grená, analiso que levavam materiais de fácil manuseio e que estavam ao alcance dos meninos. Isso é considerar o contexto - rua, as habilidades e capacidades deles - mostrando que havia um pensar nos educandos e em suas possibilidades.

Logo após perguntei que tipo de atividades eles desenvolviam com esses materiais:

Depende de uma coisa que vai sendo planejada de acordo com o menino ou a menina com quem a gente está trabalhando, então alguns, por exemplo, a gente pode levar um rádio tocar um rap, aí disso eu cheguei a fazer um cartaz com gravuras sobre rap e eles fizeram também, e fazer um rap a partir disso, porque eles entendiam muito mais de rap do que eu. (Entrevista com o educador Grená, 30/10/2009)

Grená afirmou que sabia menos de rap do que os garotos, e que ainda assim os educadores buscavam trabalhar com eles este tema, inclusive com a produção de um cartaz. Neste ponto o educando estava "ensinando" algo ao educador, mostrando os elementos que cabiam no cartaz.

Conforme aponta Freire (2007), nas atividades dessa natureza (onde o educando tem que usar suas palavras e seus gestos, a história daquilo que vive e mundo de que faz parte) o educando tem voz ativa e o educador aprende. Isso permite uma relação não hierárquica, que possivelmente provoca um comportamento de ação e reflexão para ambas as partes.

Nesse caso o educando é conduzido a refletir sobre suas palavras, seu mundo e sua cultura, visto que "não é possível linguagem sem pensamento e linguagem-pensamento sem o mundo a que se referem, a palavra humana é mais que um mero vocábulo - é palavração" (FREIRE, 2007, p. 59).

Palavra-ação. Rap-ação. Colcha-ação.

Vejo este tipo de intervenção artística-educativa dos educadores com os educandos nas ruas de Campinas como libertadora, pois os adolescentes podiam ser eles mesmos, meninos de rua, artistas, usuários de crack, sujos, possuidores de suas histórias de vida, sem que isso fosse um empecilho para que a atividade e o vínculo acontecesse. Esses fatos libertam o indivíduo a ser ele mesmo, ao menos naquele momento, e isso pode transformar a vida de um menino de rua. 
Para fundamentar essa afirmação, recorro a Reis (2000), quando diz que:

A exposição a um universo de arte não-restrito pode libertar do condicionamento estético imposto pelo mercado através da mídia, determinando um só padrão para todos, independentemente das especificidades individuais ou de grupos, em qualquer das artes.

O exercício de conhecer, tomar contato, experimentar, escolher, vale também para todo o processo de desenvolvimento do educando, na perspectiva de sua liberdade, tanto interior quanto em suas relações na sociedade. Liberdade para gostar, querer, optar, criar, fruir, viver, trocar..." (REIS, 2000, p. 72).

Porque a cultura expressa o percurso do homem, da sua luta, da sua história, uma educação que queira fortalecer a condição humana do educando tem que considerar o significado da cultura no processo educativo. Especialmente porque é a cultura que dá humanidade ao homem.

Por isso, é fundamental aproximar o educando da sua cultura de origem, articulandoo com sua história. (REIS, 2000, p. 61).

Assim, por meio da cultura dos próprios meninos eles podiam se articular com sua história e deste modo passavam a ter maior liberdade para escolher. Analiso que havia neste processo uma reflexão e uma possibilidade de ação entre o rap e seus significados em suas vidas. Trago, então, Freire (2007) quando diz:

$\mathrm{O}$ ato de conhecer envolve um movimento dialético que vai da ação à reflexão sobre ela e desta a uma nova ação. Para o educando conhecer o que antes não conhecia, deve engajar-se num autêntico processo de abstração por meio do qual reflete sobre a totalidade "ação-objeto" 10 ou, em outras palavras, sobre formas de "orientação no mundo". Este processo de abstração se dá na medida em que se lhe apresentam situações representativas da maneira como o educando "se orienta no mundo" momentos de sua quotidianeidade - e se sente desafiado a analisá-las criticamente. Ao ser uma reflexão crítica de ambos, educador-educando e educando-educador, o processo de alfabetização deve relacionar o ato de transformar o mundo com ato de pronunciá-lo.

Não há "pronúncia" do mundo sem consciente ação transformadora sobre o mesmo. (FREIRE, 2007, p. 60).

O fato de o educador conhecer o rap, de o menino conhecer a montagem de um cartaz sobre o rap, o fazer um rap conjunto levou-os a uma ação-reflexão sobre o próprio rap, que também diz muito do que é a vida de um menino de rua (eles vêm geralmente de bairros pobres, geralmente são usuário de drogas, passam inúmeras privações e se identificam com algumas letras de rap), e este é um pequeno exemplo de uma pedagogia libertadora. 


\section{COMO FORAM DUAS CENAS}

\section{Cena 1}

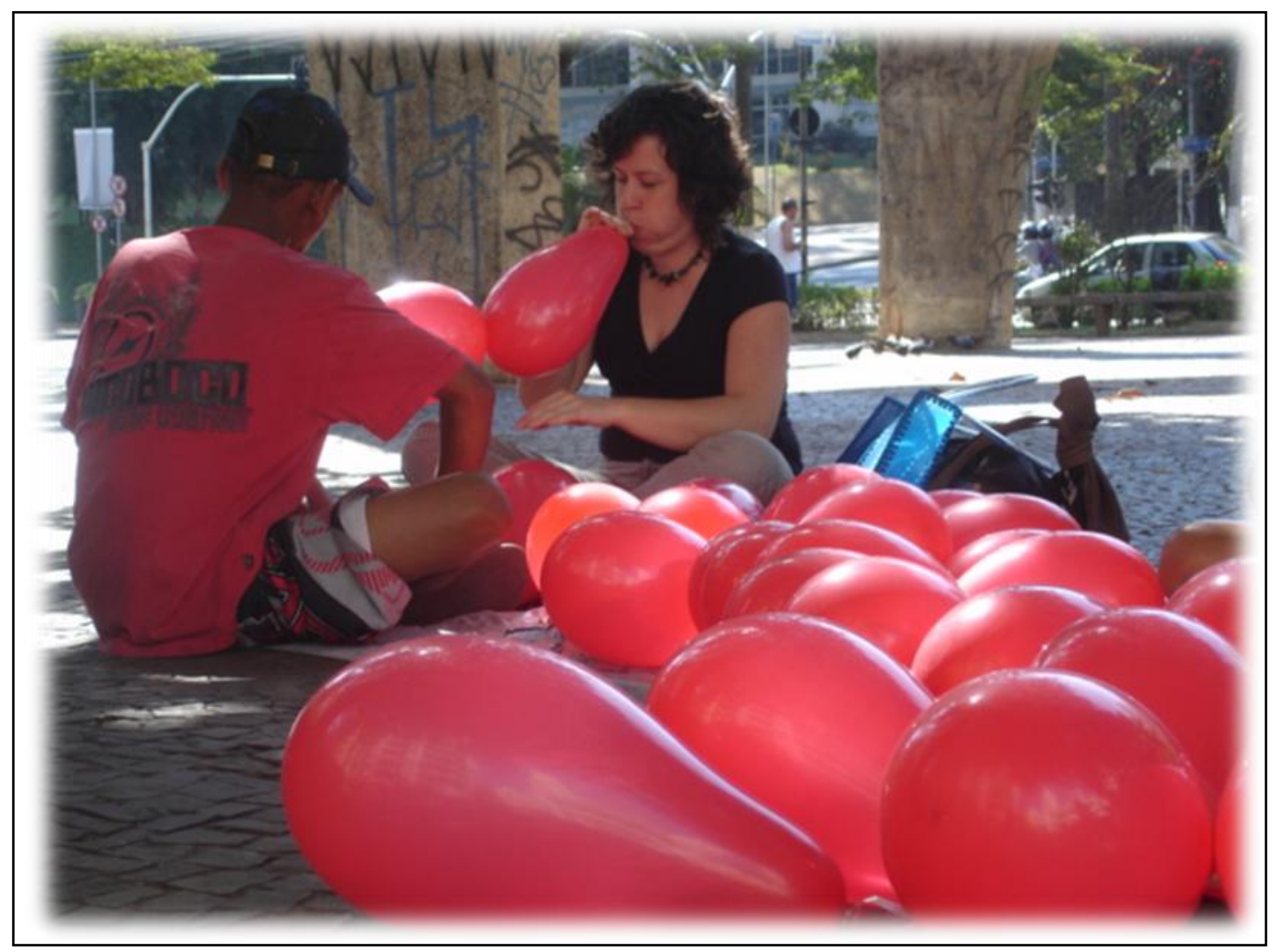

FIGURA 1 - Atividade de rua realizada pela pesquisadora junto de educadores da Casa Guadalupana. Campinas/SP, 11/07/2010.

A Cena 1 (Figura 1) mostra uma atividade de rua, uma intervenção na rua que desenvolvi com meninos e meninas depois de minha saída da Casa Guadalupana. Eu e um grupo de educadores marcamos um encontro com os meninos, pois além de nossos contratos de trabalho, havia o vínculo. Nesta figura pode-se visualizar um pouco que a arte do educador e do menino de rua dá cor à paisagem. Bexigas vermelhas, camiseta vermelha, bochecha cheia de ar. Montamos um cordão de bexigas e penduramos de uma árvore à outra, no meio de uma praça de Campinas. O que fizemos com isso? Brincamos! Decoramos o cordão com fitas coloridas, daquelas de pacote de presente, o fio da tesoura penteou o colorido das fitas, que ficaram todas enroladinhas, igual a um legítimo embrulho.

O que aconteceu aí? Um encontro. Um entrelugar. Um momento de brincadeira, de arte, de vínculo. Um encontro suficientemente bom (WINNICOTT, 1975). 
A arte da rua, do educador e do menino, funcionava como um laço, um encontro que ligava os mundos do menino de rua com os de meninos da escola, do condomínio e da prisão. A arte seria então expressão dos mundos dentro de cada um. $\mathrm{O}$ menino de rua tem todos os mundos dentro de si - do burguês ao miserável - eu também, os educadores também, os professores, prefeitos e empresários. O homem pode ser muitos em um só, indivisíveis/indivíduos.

A arte é o meio indispensável para essa união do indivíduo com o todo; reflete a infinita capacidade humana para a associação, para a circulação de experiências e idéias. Essa definição de arte como o meio de tornar-se um com o todo da realidade, como o caminho do indivíduo para a plenitude, para o mundo em geral, como a expressão do desejo do indivíduo no sentido de se identificar com aquilo que ele não é. (FISCHER, 1966, p. 13).

Fischer (1966) colocou uma definição de arte como a expressão/expansão de nosso ser atravessando as fronteiras da superficialidade.

Os pobres da cidade - principalmente a população de rua - são considerados atores principais da violência urbana e social. Os pobres da cidade atuam nesses papéis pela perspectiva dos espectadores em geral e do poder público em particular.

A arte presente na cidade também é a arte de educador com menino.

Permito-me entrar em minha imaginação e analisar os educadores como mediadores do asfalto, como plantonistas da catarse agressiva entre meninos de rua e os nãomoradores de rua. Seus instrumentos eram pincéis que lançavam tinta sobre papéis, suas dobraduras eram pássaros de papel que cruzavam o ar flutuando sobre abismos de classes sociais, suas bolas eram obstáculos a muitos transeuntes/trabalhadores que andavam apressados. O educador armava um cenário teatral com a colcha, contra a hipocrisia e a invisibilidade da segregação e do abandono social.

O educador gritava ao menino e à sociedade.

\section{Cena 2}

A arte aproxima o indivíduo de si mesmo. O menino de rua no momento de construir um origami ou pintar um rosto pequeno possuía uma mão, por vezes, pesada para os pequenos detalhes. Os gestos grosseiros, cavados por uma crueldade da rua e da aspereza do asfalto quente, afinavam-se na ampliação das atividades artísticas. O menino de rua era um artífice.

Sennett (2009) afirma que a mão envia informações mais confiáveis ao cérebro do que o olho, e a partir dessa perspectiva, que sinais recebem o cérebro de um menino de rua? 
Sinais de como riscar um isqueiro, como enrolar um baseado, como ser rápido ao bater uma carteira, como comer rápido com uma colher e como estender a mão para pedir. Mas essa mão também era incentivada a colar o papel de seda na vareta de pipa, também essa mão viajava em textura de massinha e provava de batucar pandeiro com estímulo de educador. Essas impressões desenvolvidas pela mão, em meio ao farol da Avenida Anchieta ${ }^{11}$, marcaram a memória de menino e de educador para sempre.

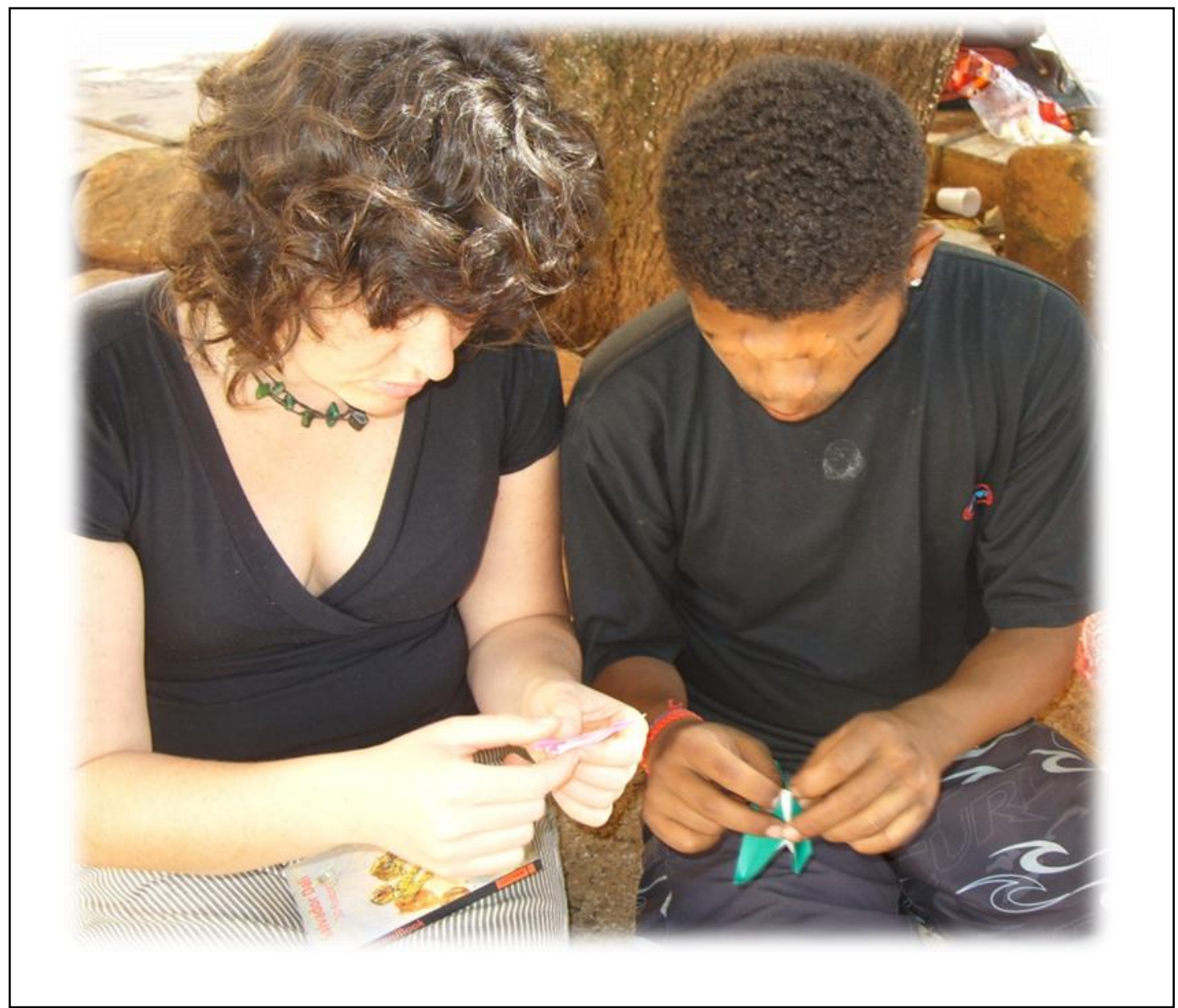

FIGURA 2 - Cena 2: Pesquisadora fazendo origami com jovem. Campinas / SP, 11/07/2010

Esta foto mostra um momento mágico. Primeiro eu fiz um origami de borboleta, junto deste jovem. Ele me acompanhou. Depois, ele foi me ensinar outro pássaro de papel que eu não sabia fazer. Eu o acompanhei. Mostro aqui que, além da mão acurada do educador, havia a mão acurada do menino, que guardava em sua memória corporal o dobrar de um quadradinho de papel que era narrativa de sua história, de sua trajetória, de seu repertório. Em

\footnotetext{
${ }^{11}$ Avenida Anchieta , localizada na região central da cidade de Campinas / SP.
} 
geral os meninos estabeleciam um compromisso com a atividade desenvolvida, fazendo-a com atenção e dedicação.

Abaixo apresento um trecho de entrevista que mostra essa dedicação:

Um episódio nós fizemos a construção e a soltação de pipas, nós fomos num parque da cidade, no parque ecológico, e todo o processo da confecção até o momento de soltar foi muito edificante, eu percebi, pela preocupação, do cuidado, o compromisso com aquele objeto que eles criaram e a expectativa com soltá-la, eu achei muito, foi uma atividade lúdica, mas eu achei muito estruturante, né, pelo comprometimento que eles tiveram com a causa ali. (Entrevista com o educador Lilás, 09/09/2009).

Ao produzirmos um desenho, uma poesia, uma palestra, uma declaração de amor, uma pirueta, a partir de um gesto espontâneo (WINNICOTT, 2005), brincamos com o mundo e assim estaremos integrados. Nossas mãos, nosso trabalho, nossa criatividade, a história de cada educador, a minha história. Todas encerradas na materialidade humana da palavra, dos gestos, das lembranças impressas no papel. O trabalho de arte do educador era um trabalho de resgate da alma e da mão destes meninos e deles próprios.

Essas cenas, esse fazer, esse modo de pesquisa permearam a produção pedagógica dos educadores, a coordenadora, a pesquisadora, a vida dos meninos de rua.

\section{COMO AMARRO E ENXERGO ESSAS CENAS}

Pude perceber que alguns educadores se mostraram mais afinados a uma proposta pedagógica baseada no vínculo, em uma pedagogia do estar e fazer junto; outros se mostraram mais adeptos a uma pedagogia do brincar; outros ainda trabalhavam mais para o lado das artes; outros das conversas, mas todos conviviam, com conflitos inerentes à vida humana, enlaçados pelo mesmo objetivo: a transformação da vida do menino de rua, e a transformação da vida do educador.

Encontrei no termo suficientemente bom a palavra que melhor definiu a atuação desses educadores e a criação do entrelugar também suficientemente bom. A banca de qualificação acenou-me um ponto interessante: encontrei o conceito de educadores suficientemente bons para meninos que não tiveram mães suficientemente boas. Pois aí está a dialética da vida.

E essa constatação reafirma o que desde 2006 se trabalhou na Casa Guadalupana: a importância da multidisciplinaridade, da riqueza das muitas formações, da riqueza das muitas experiências de vida. Constatei, inclusive, que a formação acadêmica não garante um 
bom trabalho com esses meninos e meninas. A questão de como se criar um vínculo, estabelecer confiança mútua, ter sensibilidade nas delicadas situações não se aprende nos bancos universitários, mas no chão das praças, dia-a-dia após cada conversa, desenho e abraço com esses meninos.

Arrisco dizer ainda que nem somente os chãos das praças podem "ensinar" esse trabalho. Ser educador de menino de rua, assim como ser professor, psicólogo, médico, ou seja, trabalhar com gente, e gente que sofre, pressupõe haver uma disposição emocional individual, uma vontade própria, um impulso, um desejo que não tem a ver com a formação acadêmica, mas com empatia pelo outro, por acreditar que a relação com o outro pode ser vetor de uma mudança individual e social.

A educação não é um trabalho técnico. A educação é um trabalho que se dá pela relação humana, e isso é muito difícil. Numa educação técnica pode haver troca? Ou pode apenas ser fria e sofrida, e, portanto, bancária? Parece-me que uma condição para que haja prazer pelo aprendizado, e sentido em estar aprendendo, é ter uma relação educador-educando alegre, deslumbrada e que use os conflitos para o aprendizado.

Por fim, considero a colcha uma intervenção artística urbana necessária, dando visibilidade a um indivíduo criativo, cheio de energia, que aprecia o universo estético e cultural para além das veredas da droga, do crime e do sofrimento.

Considero ainda que a colcha e a arte não salvarão nenhum menino de rua de sua situação social e econômica, mas essas ferramentas de trabalho lançam reflexão suficiente para que eles pensem sobre suas vidas e possam fazer escolhas.

Foi essa a pedagogia que vi, vivi e senti com esses educadores e esses meninos.

\section{REFERÊNCIAS}

BAUER, M. W; GASKELL, G. (Org.). Pesquisa qualitativa com texto, imagem e som: um manual prático. São Paulo, SP: Vozes, 2007.

BENJAMIN, W. Sobre Arte, técnica, linguagem e política. Lisboa: Relógio D’Água Editores, 1992.

FISCHER, E. A necessidade da arte: uma interpretação marxista. Rio de Janeiro, RJ: Zahar Editores, 1966.

FREIRE, P. Ação cultural para a liberdade e outros escritos. São Paulo, SP: Paz e Terra, 2007. 
Pedagogia da autonomia: saberes necessários à prática educativa. São Paulo, SP: Paz e Terra, 1996.

Pedagogia do Oprimido. Rio de Janeiro, RJ: Paz e Terra, 1978.

REIS, A. M. B. (Org.). Plantando axé: uma proposta pedagógica. São Paulo, SP: Cortez, 2000.

SENNETT, R. O artífice. Rio de Janeiro, RJ: Record, 2009.

STRAZZACAPPA, M.; ALBANO, A. A.; AYOUB, E. Apresentação. Pro-Posições,

Campinas, v. 21, n. 2, ago. 2010.

WINNICOTT, D. W. O brincar e a realidade. Rio de Janeiro: Imago, 1975.

Privação e delinquência. São Paulo: Martins Fontes, 2005.

1988.

. Textos selecionados: da pediatria à psicanálise. Rio de Janeiro, RJ: Francisco Alves, 